\title{
Organochlorine Pesticides Residues in Soil of Cocoa Farms in Ondo State Central District, Nigeria
}

\author{
Ademola F. Aiyesanmi ${ }^{1}$ \& Gideon A. Idowu ${ }^{1}$ \\ ${ }^{1}$ Department of Chemistry, Federal University of Technology, P.M.B.704, Akure, Nigeria \\ Correspondence: Ademola F. Aiyesanmi, Department of Chemistry, Federal University of Technology, \\ P.M.B.704, Akure, Nigeria. Tel: 234-803-350-1293. E-mail: demolaktp@yahoo.co.uk
}

Received: March 28, 2012 Accepted: May 10, 2012 Online Published: June 1, 2012

doi:10.5539/enrr.v2n2p65 URL: http://dx.doi.org/10.5539/enrr.v2n2p65

\begin{abstract}
Ondo State being the highest producer of Cocoa in Nigeria constitutes the most probable area with the highest use of chemical pesticides to enhance cocoa production. As effective as these chemicals may be in achieving this goal, the incidence of their residues on non-targeted substances and the total environment, with the attendant adverse effects have being of serious concerns. Our objective in this paper is to assess contamination of farm soils by organochlorine pesticides applied on cocoa farms within the Central Senatorial District of Ondo State, Nigeria. Soil samples were collected from selected cocoa farms and analysed for organochlorine pesticides residues using GC-MS. Some soil physicochemical properties including $\mathrm{pH}$, particle size and organic matter that may influence the dynamics of the pollutants were also determined. Organochlorine compounds detected at varied concentrations include Endosulfan I and Endosulfan II occurring most frequently with highest concentrations of $350.10 \mathrm{mg} / \mathrm{kg}$ and $3.55 \mathrm{mg} / \mathrm{kg}$ respectively. Other organochlorine compounds detected were Heptachlor, Heptachlor epoxide, Aldrin, Deldrin, isomers of Benzene hexachloride: $\alpha$-BHC, $\beta$-BHC, $\delta$-BHC, and $\mathrm{Y}$-BHC (lindane). The concentrations of the organochlorine pesticides $(\mathrm{mg} / \mathrm{kg})$ measured in the soil samples showed significant $(\mathrm{p}<0.05)$ correlation with the total organic matter contents of the soil. Findings from this research thus, provide information on the current and health risk residue levels of organochlorine pesticides in soil from this region with which future environmental performance on the use of pesticides on cocoa farms could be progressively monitored.
\end{abstract}

Keyword: Organochlorine Pesticides (OCPs), physicochemical properties, soil, cocoa farm

\section{Introduction}

The invention of chemical pesticides has, no doubt, brought a great relief to agricultural production in terms of crop protection and yield, making their use almost inevitable. However, the incidence of residues from their use on non-targeted substances and the environment in general continues to generate serious concerns that the adverse effects of their use may well outweigh the overall benefits derived from them. Organochlorine compounds have a long history of widespread use as pesticides around the world. They are a class of non-polar toxic chemical compounds containing carbon, hydrogen and chlorine, and are composed of five broad groups namely: the Dichloro-diphenyl-trichloro ethane (DDT) and analogues (e.g. dicofol, methoxychlor); the Hexacholrocyclohexane or Benzene hexachloride and their isomers (e.g. lindane, the $Y$ - isomer); the Cyclodienes (e.g. chlordane, heptachlor, aldrin, dieldrin, endrin, endosulfan, isobenzan); the Chlordecones, Kelevan, Murex; and the Toxaphenes (Pope, Skurky- Thomas \& Rosen, 1994). Organochlorine Pesticides (OCPs) are ubiquitous environmental contaminants and have also been classified as a group of Persistent Organic Pollutants (POPs) due to their inability to break down in the environment; resisting degradation by chemical, physical, microbiological, and biological means (Swackhamer \& Hites, 1988; National Center for Environmental Health (NCEH), 2005; Darko \& Acquaah, 2007). Organochlorine pesticides have half-lives ranging from months to years, and in some cases decades (Cremlyn, 1991). They are toxic to humans and other animals, and very highly toxic to most aquatic life. Organochlorines can have serious short-term and long-term impacts even at low concentrations. In addition, non-lethal effects such as immune system and reproductive damages of most organochlorines may be very significant (Lemaire, Terouanne, Mauvais, Michel \& Rahmania, 2004). They build up in the fatty tissues of humans, animals and plants, and most often are attracted to fatty tissues and organs, and are accumulated significantly in animals such as fish (Swackhamer \& Hites, 1988; Bentzen et al, 2008). Increase in the concentration of organochlorine molecules up the food chain, with bioaccumulation and biomagnifications 
taking place in higher organisms including man had been reported (Australian Department of Environment \& Heritage (DEH), 1997; Ize-Iyamu, Abia \& Egwakhide, 2007). Significant exposure occurs through the consumption of contaminated agricultural products containing residues of these pesticide or their degradation products (Hall, 1999). An estimated 3 million cases of pesticide poisoning occur each year world-wide with 95\% of the fatal poisoning cases occurring in the developing countries (Pope et al, 1994). Despite the ban pronounced on most of these toxic organochlorine compounds, they are still being used in most developing nations both domestically and on agricultural crops. This continued use of organochlorine pesticides has remained a matter of international concern because of their persistence and long-distance carriage through oceanic currents and atmospheric transports (Bentzen et al, 2008; Caldas, Coelho, Souza \& Siba, 1999). Osibanjo (1994) identified the high potency/efficacy and lower cost of organochlorine pesticides compared with alternative pesticides as the reasons for their continued use in most developing countries, including Nigeria. The main use of the pesticides in these countries is their application as insecticides on cash crops.

Ondo State is the highest producer of Cocoa in Nigeria, with an estimated output of 45,004.5 Metric Tonnes in 2007, representing 40\% of the total cocoa production in Nigeria (Aikpokpodion, 2010; Ajayi, Afolabi, Ogunbodede \& Sunday, 2010). The State constitutes the most probable area with the highest agricultural use of pesticides in Nigeria, particularly in the extensive cocoa plantations found in the Central Senatorial District of the state. A survey of the local markets within this region confirmed the sales of pesticides containing organochlorines; mainly lindane, endosulfan, and heptachlor, and this not undermining the sales and use of other toxic organochlorines not openly displayed on market stalls or not bearing labels about their chemical composition. Unfortunately, the few available reports and reviews by Atuma and Okor (1985), Osibanjo and Bamgbose (1990), Osibanjo and Adeyeye (1995), Uyimandu (2002), Ize-Iyamu et al. (2007), Adeyemi, Ukpo, Anyakora and Unyimadu (2008) on the levels of organochlorine pesticides contamination of some parts of Nigeria provided no data about the Ondo State Central Senatorial District with presumably heavy use of organochlorine pesticides for cocoa production. It is therefore worthwhile to investigate the level of contamination of the various environmental phases within the region by organochlorine pesticides applied on the cocoa farms. Thus, the present study examines the level of Organochlorine Pesticides (OCPs) residues in the soil samples of some Cocoa- producing areas of Ondo State to complement the available data on pesticides residues levels in Nigerian soils

\section{Materials and Methods}

\subsection{Study Area}

The study area for the research covers three major cocoa - producing local governments within the Ondo State Central Senatorial District where pesticides are applied on cocoa farms by farmers. The Local Government Area (LGA) include Akure South, Ifedore and Idanre (Figure. 1) located between $07^{\circ} 04^{\prime}-07^{0} 20^{\prime} \mathrm{N}$ and $005^{\circ} 06^{\prime}-$ $005^{0} 14^{\prime} \mathrm{E}$ and are within the same geographical zone. Three farms (each covering approximately 2 hectares of land) were selected in each of the local governments and topsoil samples were taken at five randomly located points from each farm.

\subsection{Sampling and Sample Preparation}

A standard stainless steel hand auger was used to take the topsoil samples at a depth of $20 \mathrm{~cm}$ because nutrients uptake by plants is usually within this horizon, which is also most prone to surface runoff into water bodies. Five randomly selected points within the farms in each of the three local government areas were sampled, given 15 soil samples per local government area and a total of 45 samples in all. All sampling points were geographically referenced with a Global Positioning System (Garmin 12 Model). The soil samples were air-dried in the laboratory for 2 weeks, picked for obvious non-soil and extraneous materials, ground in agate mortar and sieved through a $2 \mathrm{~mm}$ mesh. These were stored in black polythene bags prior analysis.

\subsection{Physicochemical Analysis of Soil Sample}

The $\mathrm{pH}$ of the sieved soil samples in water was determined by the method of Hendershot, Lalande and Duquette (1993). The soil particle size was determined by hydrometer method described by Shedrick and Wang (1993), while the wet oxidation method of Walkley and Black described by Schulte (1995) was used to determine the organic carbon contents from which organic matter content was calculated. 


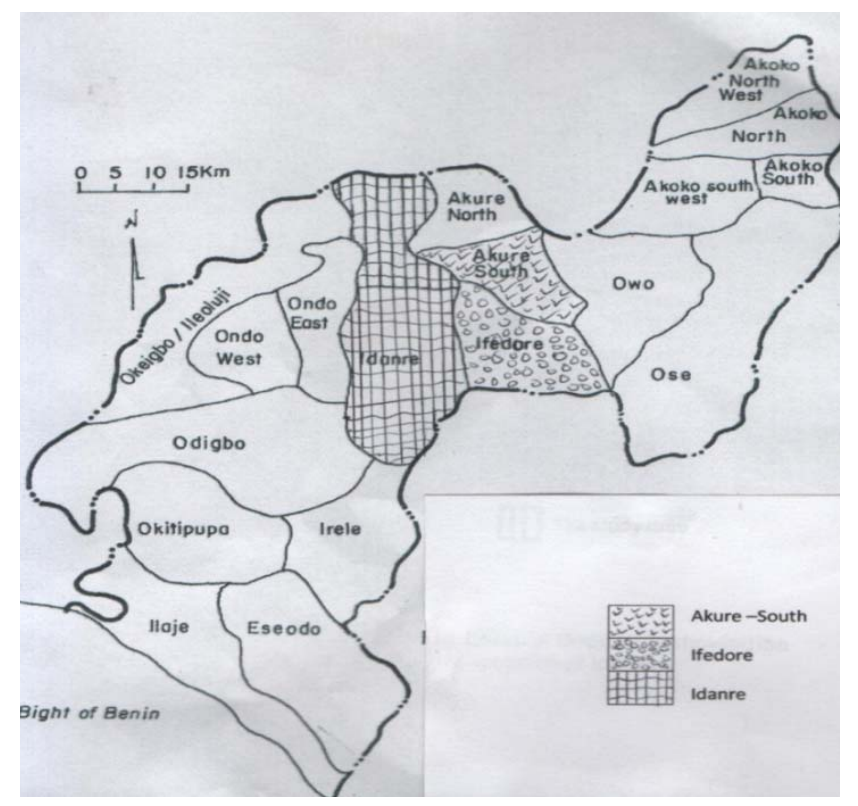

Figure 1. Ondo State map showing the study areas within the Central Senatorial District

\subsection{Extraction of Organochlorine Residues from Soil Sample}

All the reagents used were of analytical grade and glass wares used for the study were cleaned as prescribed by Method 1699 of USEPA (2007). Extraction of the soil samples was carried out by the method described by Ize-Iyamu et al. (2007). $10 \mathrm{~g}$ of each sample and $20 \mathrm{~g}$ of anhydrous sodium sulphate were ground into dry powder. The ground sample was extracted with $150 \mathrm{ml}$ of a mixture of Acetone and $\mathrm{n}$-Hexane (2:1). After extraction, the extract was transferred into a round bottomed-flask connected to a pre-weighed receiver through a Liebig condenser and concentrated to about $20 \mathrm{ml}$ on a water bath maintained between 50 and $55^{\circ} \mathrm{C}$. The remaining solvent in the concentrated extract was evaporated using a rotary evaporator. The almost - dry extracts were cleaned up in a micro-columns as described in ASTM (1979). $2 \mathrm{~g}$ of activated silica gel was packed into a chromatographic micro-column of $10 \mathrm{~mm}$ internal diameter. and approximately $10 \mathrm{~cm}$ long. The silica gel was conditioned with $10 \mathrm{ml} \mathrm{n}$-Hexane, while the sample extracts were dissolved in $5 \mathrm{ml} \mathrm{n}$-Hexane before they were loaded onto the separate micro-column. Elution of each of the sample was done with $50 \mathrm{ml}$ of ethyl-acetate: hexane mixture (9:1). The eluents were then concentrated on a rotary evaporator at about $45^{\circ} \mathrm{C}$ and under a gentle stream of nitrogen gas. The almost-dry concentrates were then dissolved in $2 \mathrm{ml}$ acetone and were transferred into vials for subsequent injection into the Gas Chromatograph.

\subsection{Sample Analysis for Organochlorine Pesticides Residues}

The internal standard technique was employed to analyse the extracted samples. The organochlorine standard containing a mixture of 14 organochlorine compounds of high putiry (alpha-BHC, beta-BHC, Lindane, delta-BHC, Heptachlor, Aldrin, Heptachlor - epoxide, Endosulfan I, p,p'- DDE, Dieldrin, Endrin, Endosulfan II, p,p'- DDT, and Endosulfan sulphate) was prepared at concentrations ranging from 0.100 to $2.000 \mathrm{ppm}$, with Anthracene, PCB-153, and PF-38 added as internal standards. The modern Shimadzu GC-MS QP-2010 was employed in analysing the standards and the calibration curve for each compound was prepared automatically. Both the control and main soil samples extract from clean - up were then analysed under the same conditions as for the standards, and in the Selective Ion Mode (SIM) with $\mathrm{m} / \mathrm{z}$ values ranging from 65 to 274 . The efficiency of the method was validated with recoveries of studies. Fortification of reference material without pesticides residues with four organochlorine compounds at two concentration levels $0.1 \mathrm{mg} / \mathrm{kg}$ and $1.0 \mathrm{mg} / \mathrm{kg}$ was carried out in triplicate and the same method of extraction and cleane-up was followed. Other quality assurance measures applied in the laboratory included rigorous contamination control procedures (washing and cleaning procedures), monitoring of blank levels of solvents and analysis of procedural blanks.

\section{Results and Discussions}

Tables 1 presents the physicochemical properties of the soil samples from the selected cocoa farms in the Ondo 
Central Senatorial District and provide an insight into the nature of the soils being investigated. The soil particle size distribution reveals the textural class of the soils as mainly sandy - loamy (sand - silt), characteristic of most agricultural fields in region. The soil reaction $(\mathrm{pH})$ varied from one location to another on the same farm as well as from farm to farm within the study area. Employing the classification of soil $\mathrm{pH}$ by Vitosh, John and Mengel (1995), the pH of the soil samples from Akure - South ranged from "slightly acidic" to "very slightly alkaline"; Ifedore from "strongly acidic" to "very slightly alkaline"; and Idanre from "very slightly acidic" to "very slightly alkaline". The marked variation in the $\mathrm{pH}$ values is not unexpected as many dynamic soil reactions utilizing $\mathrm{H}^{+}$ions such as oxidation - reduction, complexation - dissociation, and sorption - desorption occur to a different extent in different parts of a soil (Sparks, 2003). The soil samples have relatively high Organic Matter content (OM) with reference to FAO classification of soil organic matter (FAO, 1990). Soil pH, organic matter and clay contents are known to influence the dynamics and behavior of both inorganic and organic pollutants in soil (Department of Petroleum Resources (DPR), 2002; Gale, Adams, Wixson, Loftin \& Huang, 2004; Aiyesanmi, Tomori \& Owolabi, 2008).

Table 1. Range and mean physicochemical characteristic of soil samples from the study area

\begin{tabular}{llllll}
\hline Sample & Sand (\%) & Clay (\%) & Silt (\%) & $\mathrm{pH}$ & $0 . \mathrm{M}$ \\
\hline AKS & & & & & \\
Range & $59.42-67.48$ & $11.06-13.66$ & $20.83-27.60$ & $6.20-7.70$ & $3.61-8.07$ \\
Mean & 63.30 & 12.08 & 24.61 & 7.19 & 5.33 \\
Std & 2.48 & 0.85 & 1.95 & 0.49 & 1.37 \\
IFD & & & & & \\
Range & $59.82-65.57$ & $12.25-16.07$ & $20.10-27.29$ & $4.90-7.50$ & $3.42-8.87$ \\
Mean & 63.06 & 13.43 & 23.51 & 6.24 & 6.40 \\
Std & 2.13 & 1.18 & 2.33 & 0.73 & 1.57 \\
IDR & & & & & \\
Range & $65.26-68.93$ & $6.66-11.89$ & $20.47-26.26$ & $6.40-7.20$ & $3.51-8.16$ \\
Mean & 66.66 & 10.97 & 22.43 & 6.88 & 5.80 \\
Std & 1.22 & 5.68 & 1.55 & 0.19 & 1.84 \\
\hline
\end{tabular}

AKS $=$ Akure South; IFD $=$ Ifedore; IDR $=$ Idanre

The observed Retention Times (RT) for each organochlorine compounds in the standard under the conditions employed are shown in Table 2. Percent recoveries of the four pesticides from fortified reference material extracts are presented in Table 3. Satisfactory results were obtained for all the pesticides at the two fortification levels. The organocchlorine pesticides were recovered in the range of $79-96 \%$ and $82-90 \%$ for 0.5 and 1.0 $\mathrm{mg} / \mathrm{kg}$, respectively. These results showed that the method has suitable range with good reproducibility.

Table 2. Retention time for various organochlorine compounds

\begin{tabular}{ll}
\hline Standard & Retention time (min) \\
\hline Alpha - BHC & 8.31 \\
Beta - BHC & 8.89 \\
Lindane & 8.99 \\
Delta -BHC & 9.58 \\
Heptachlor & 10.00 \\
Aldin & 10.64 \\
Heptachlor - epoxide & 11.43 \\
Endosulfan I & 12.10 \\
P, P'- DDE & 12.44 \\
Dieldrin & 12.61 \\
Endrin & 13.04 \\
Endosulfan II & 13.31 \\
P, P'-DDT & 13.96 \\
Endosulfan sulphate & 14.03 \\
\hline
\end{tabular}


Table 3. Percent recovery of selected organochlorine pesticides

\begin{tabular}{llll}
\hline Pesticides & Retention Time $(\mathrm{min})$ & Fortification Level $(\mathrm{mg} / \mathrm{kg})$ & Recovery $(\%)$ \\
\hline$\beta$ - BHC & 8.89 & 0.1 & $96 \pm 1.5$ \\
& & 1.0 & $89 \pm 2.0$ \\
Heptachlor & 10.00 & 0.1 & $92 \pm 0.7$ \\
& & 1.0 & $90 \pm 1.0$ \\
Endosulfan & 112.10 & 0.1 & $79 \pm 0.7$ \\
& & 1.0 & $82 \pm 1.3$ \\
Dieldrin & \multirow{2}{*}{12.61} & 0.1 & $84 \pm 1.7$ \\
& & 1.0 & $86 \pm 1.0$ \\
\hline
\end{tabular}

The concentrations of the various organochlorine pesticides detected in the soil samples are presented in Tables 4 , 5 and 6 for the respective local government areas. The specific organochlorine compounds detected in the samples and their concentrations differed markedly. The three isomers of Benzene hexachloride (BHC) or Hexa-chlorocyclohexane $(\mathrm{HCH}): \alpha-\mathrm{BHC}, \beta$-BHC, and $\delta$-BHC, were detected in few soil samples from Akure -south and Ifedore (AKS3, IFD13, IFD15), while no detectable levels of the isomers were found in the soil samples for Idanre. The measured concentrations of the three isomers of $\mathrm{BHC}$ (or $\mathrm{HCH}$ ) are attributable to the use of the $\gamma$ - isomer (lindane) popularly called Gammalin 20, which is the only BHC isomer with powerful insecticidal action. This is because only Akure-South and Ifedore areas with detectable levels of lindane at $0.375 \mathrm{mg} / \mathrm{kg}$ (in AKS15) and $0.217 \mathrm{mg} / \mathrm{kg}$ (in IFD15) respectively, gave quantifiable levels of $\alpha, \beta$, and $\delta-\mathrm{BHC}$, while lindane was not detected in all the samples from Idanre area. Five organochlorine compounds belonging to the cyclodiene group were also detected in the various samples. These are heptachlor, heptachlor epoxide, aldrin, dieldrin, and endosulfan. Heptachlor was found in the soil samples from only one of the farms in Ifedore area and at very high concentrations in soil samples from Akure-South. However, the metabolic product of heptachlor, heptachlor epoxide, appeared more frequently in the samples. The levels of heptachlor epoxide found in the samples may be directly related to the application of heptachlor on the farms, since heptachlor is only converted to heptachlor epoxide in plant and insect tissues. The epoxide is more chemically potent than heptachlor itself (Cremlyn, 1991). Aldrin and dieldrin were detected more frequently in the soil samples from Ifedore and Idanre areas and dieldrin at Akure South area. The two conformational isomers of endosulfan: $\alpha$ - endosulfan (endosulfan I) and $\beta$ - endosulfan (endosulfan II) occurred most frequently compared to the other organochlorine compounds. Much higher concentrations of endosulfan I was found in the samples than the corresponding endosulfan II.

Table 4. Concentration of organochlorine pesticide residues $(\mathrm{mg} / \mathrm{kg})$ in soils from selected cocoa farms in Akure-South LGA

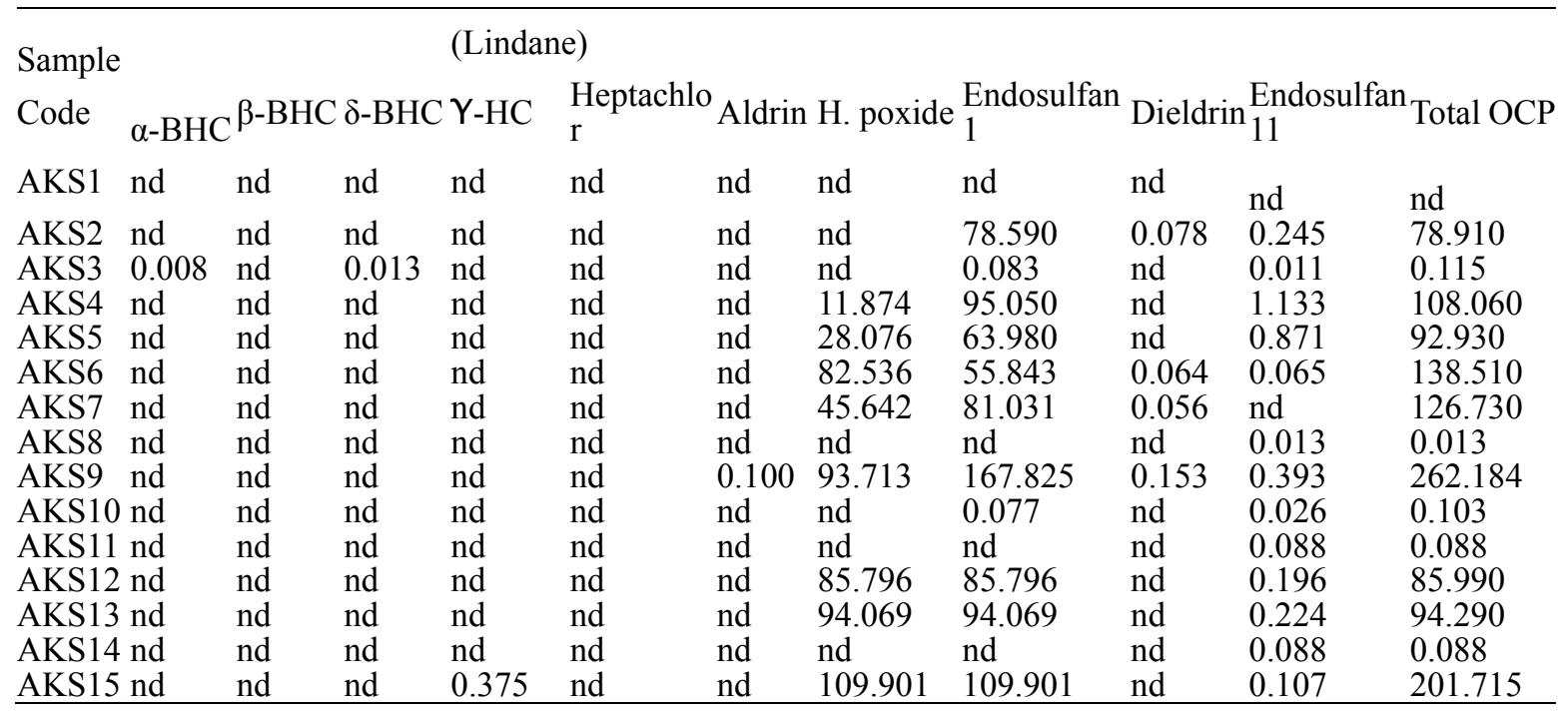

* None organochlorine pesticide $; \mathrm{nd}=$ Below instrument detection limit 
AKS- Akure-South Area Soil Sample: 1-5 = Samples from Farm 1; 6-10 = Samples from farm 2; 11-15= Samples from Farm 3

Table 5. ncentration of organochlorine pesticide residues $(\mathrm{mg} / \mathrm{kg})$ in soils from selected cocoa farms in Ifedore LGA

\begin{tabular}{|c|c|c|c|c|c|c|c|c|c|c|c|}
\hline \multirow{2}{*}{$\frac{\text { Sample }}{\text { Code }}$} & \multirow{2}{*}{$\alpha-\mathrm{BHC}$} & \multirow{2}{*}{\multicolumn{2}{|c|}{$\beta-\mathrm{BHC} \delta-\mathrm{BHC}$}} & \multicolumn{8}{|c|}{ (Lindane) } \\
\hline & & & & \multicolumn{2}{|c|}{$\begin{array}{l}\text { Y- } \\
\text { BHC }\end{array}$} & \multicolumn{2}{|c|}{ Aldrin H. epoxide } & Endosulfan I & Dieldrin & \multicolumn{2}{|c|}{$\begin{array}{l}\text { Endosulfan Total } \\
\text { II } \quad \text { OCP }\end{array}$} \\
\hline IFD1 & nd & nd & nd & nd & nd & nd & nd & 150.782 & nd & 1.817 & 152.600 \\
\hline IFD2 & nd & nd & nd & nd & nd & nd & nd & nd & nd & 0.041 & 0.041 \\
\hline IFD3 & nd & nd & 0.013 & nd & nd & nd & nd & 161.613 & 0.439 & 1.225 & 163.280 \\
\hline IFD4 & nd & nd & nd & nd & nd & nd & nd & 155.574 & 0.367 & 1.633 & 157.570 \\
\hline IFD5 & nd & nd & nd & nd & nd & 0.261 & nd & 171.895 & 0.449 & 1.711 & 174.320 \\
\hline IFD6 & nd & nd & nd & nd & nd & & nd & 263.129 & 0.551 & 1.031 & 264.710 \\
\hline IFD7 & nd & nd & nd & nd & nd & 0.223 & nd & 129.873 & 0.33 & 2.226 & 132.650 \\
\hline IFD8 & nd & nd & nd & nd & nd & 0.039 & nd & 87.896 & 0.252 & 2.530 & 90.710 \\
\hline IFD9 & nd & nd & nd & nd & nd & & nd & 98.000 & 0.221 & 2.052 & 100.270 \\
\hline IFD10 & & nd & nd & nd & nd & 0.027 & nd & 261.301 & 0.489 & 1.076 & 262.890 \\
\hline IFD11 & nd & nd & nd & nd & nd & 0.035 & nd & 111.795 & 0.118 & 1.646 & 113.590 \\
\hline IFD12 & nd & nd & nd & nd & nd & nd & nd & 141.613 & 0.054 & 0.227 & 141.890 \\
\hline IFD13 & 0.295 & 0.617 & 1.075 & nd & nd & nd & 0.2873 & 350.100 & 0.211 & 0.063 & 352.650 \\
\hline IFD14 & & nd & nd & nd & 2.493 & nd & nd & nd & nd & nd & 2.490 \\
\hline IFD15 & nd & nd & 0.321 & 0.0217 & 0.134 & 0.219 & 0.028 & nd & nd & 0.159 & 0.880 \\
\hline
\end{tabular}

*None organochlorine pesticide $; \mathrm{nd}=$ Below instrument detection limit

IFD - Ifedore Area Soil Sample: 1-5= Samples from Farm 1; 6-10= Samples from farm 2;11-15 = Samples from Farm3

Table 6. Concentration of organochlorine pesticide residues $(\mathrm{mg} / \mathrm{kg})$ in soils from selected cocoa farms in Idanre LGA

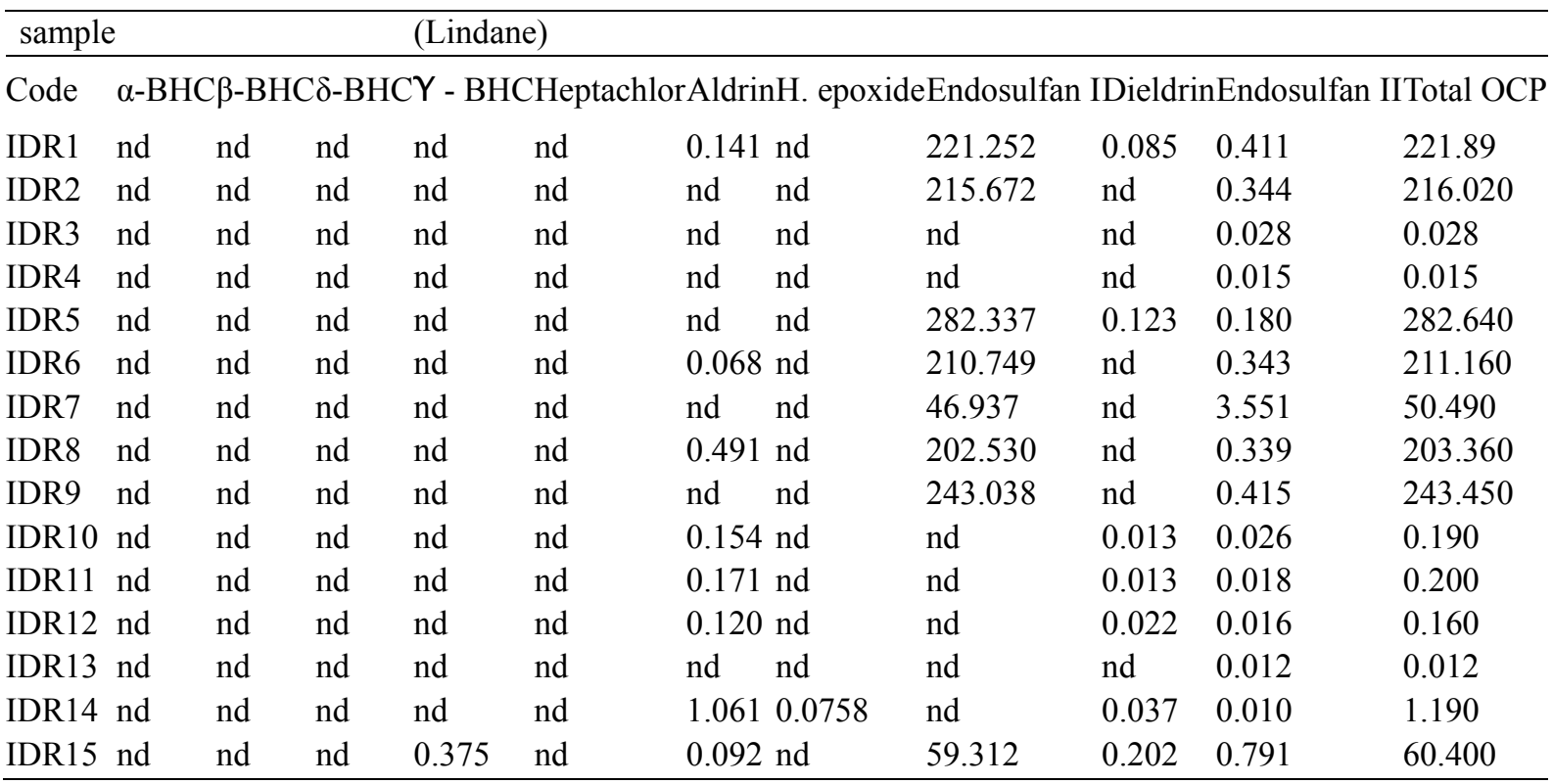

* None organochlorine pesticide $; \mathrm{nd}=$ Below instrument detection limit

IDR - Idanre Area Soil Sample: 1-5= Samples from Farm 1; 6-10= Samples from farm 2; 11-15= Samples from Farm 3

The much higher concentrations of endosulfan I relative to those of endosulfan II in the samples may be attributed to two reasons. Firstly, the manufactured technical endosulfan normally contains about $67 \%$ 
endosulfan I by mass of the total endosulfan content, while endosulfan II constitutes only $32 \%$ (World Health Organisation (WHO), 1990). It is, therefore, not unexpected that more of endosulfan I would be found in the environment wherever the pesticide is applied. Secondly, endosulfan I is thermally stable while endosulfan II is unstable and may be slowly converted to endosulfan I in the environment (Hapeman, Schmidt \& Rice, 1997; Rice, Hapeman \& Chernyak, 1997). However, the high concentrations of endosulfan I and II detected in the samples may be an indication of recent application of the pesticides on some of the cocoa farms, as endosulfan is easily degraded and does not accumulate in the environment unlike most other organochlorines (Cremlyn, 1991). This observation is further corroborated by the fact that endosulfan sulphate, which is the primary degradation product of endosulfan was not detected.

The occurrence and level of some of the organochlorine compounds: $\alpha$-BHC, $\beta$-BHC, $\delta$-BHC, $\gamma$-BHC (lindane), heptachlor, heptachlor epoxide, endosulfan I, endosulfan II, aldrin and dieldrin found in the soil samples from these farms are worrisome. Apart from the potential danger they may pose to the soil organisms, there is also the possibility of translocation of these residues from the soil into cocoa fruits through the root system, and into other crops like vegetables that are commonly intercropped within cocoa farms, thereby constituting serious health risks (Townsend \& Specht, 1975; Quintero et al., 2008). Contamination of surrounding water bodies by pesticides residues through runoff from contaminated farm soils is also likely as widely reported (Castilho, Fenzl, Guillen \& Nascimento, 2000; Konstantinou, Hela, \& Albanis, 2006; Pazou et al., 2006; Sarkar et al., 2008).

Correlation analysis carried out to examine the relationship between the soil physico-chemical properties and the quantity of organochlorine pesticide (OCP) residues measured in the soil matrices is presented in Table 7. The resulting correlation coefficients between soil physico-chemical properties and the mean total organochlorine pesticides residues, revealed high significant $(\mathrm{p}<0.05)$ correlation only between the organic matter content and the OCP measured in the soil throughout the entire study area. This suggests that pesticides residues levels in the soil are possibly more associated with organic matter content of the soil, and which could be attributed to the fact that organochlorine pesticide molecules have high tendency of binding to organic carbons in soil, similar to fats or lipids of plants and animals as reported by Swackhamer et al. (1988) and Bentzen et al. (2008). The observed correlations coefficients between other measured physico-chemical parameters of the soil and the OCP showed no significant correlation, indicating little influence of these soil characteristics on the OCP level.

Table 7. Pearson correlation of soil physico-chemical properties with total organochlorine pesticides residues concentrations

\begin{tabular}{|c|c|c|c|c|c|}
\hline \multirow{2}{*}{\multicolumn{2}{|c|}{ Sand (\%) }} & & & & \\
\hline & & Clay $(\%)$ & Silt (\%) & $\mathrm{pH}$ & O.M $(\%)$ \\
\hline AKS TOCP & -0.3135 & 0.3514 & 0.2466 & -0.364 & $0.9302 *$ \\
\hline IFD TOCP & -0.0175 & 0.2785 & -0.1254 & -0.4556 & $0.9596^{*}$ \\
\hline IDR TOCP & 0.1680 & -0.3384 & 0.2585 & -0.3015 & $0.9476^{*}$ \\
\hline
\end{tabular}

* Significant correlation at $\mathrm{p}<0.05$

TOCP $=$ Mean total organochlorine pesticides

\section{Conclusion}

This study has provided data on the level of contamination of farm soils by organochlorine pesticides applied on cocoa farms within the Central Senatorial District of Ondo State. Varied concentrations $\alpha$-BHC, $\beta$-BHC, $\delta$-BHC, Y-BHC (lindane), heptachlor, heptachlor epoxide, endosulfan I, endosulfan II, aldrin and dieldrin were found in the different samples. In particular, the concentrations and frequency of occurrence of endosulfan I, endosulfan II, heptachlor epoxide and aldrin in the soil samples were very high and are of serious concern. Apart from the potential danger they may pose to the soil organisms, their possible translocation into edible parts of crops and emission into surrounding water bodies have elicited a great deal of interest as these are currently being investigated.

\section{Acknowledgement}

The authors wish to acknowledge the technical assistance rendered by the Chemical Laboratory of the National Food and Drug Administration and Control, Oshodi, Nigeria

\section{References}

Adeyemi, D., Ukpo, G., Anyakora, C. \& Unyimadu, J. P. (2008). Organochlorine pesticide residues in fish 
samples from Lagos Lagoon, Nigeria. American Journal of Environmental Science, 4 (6), 649-653.

Aikpokopodion, P. E. (2010). Nutrients dynamics in cocoa soils, leaf, and beans in Ondo State, Nigeria. Journal of Agricultural Science, 1(1), 1-9.

Aiyesanmi, A. F., Tomori, W. B., \& Owolabi, B. J. (2008). Relative partitioning of some heavy metals in dumpsite soil using chemical speciation technique. International Journal of Chemical Sciences, 1(1), 96-104.

Ajayi, J. R., Afolabi, M. O., Ogunbodede, E. F., \& Sunday, A. G. (2010). Modelling rainfall as a constraining factor for cocoa yield in Ondo State. American Journal of Science and Industrial Research, 1(2), 127-134. http://dx.doi.org/10.5251/ajsir.2010.1.2.127.134

ASTM, (1979).The American Society for testing and Material, Method D 3086-79. Standard Test Method for Organochlorine in Water. Additional clean-up procedure using silica gel.

Atuma, S., \& Okor, D. (1985). Gas chromatographic determination of pentacholrophenol in human blood and urine. Bulletin of Environmental Contamination and Toxicology, 62, 199-206.

Bentzen, T. W., Follman, E. H., Amstrup, S. C., York, G. S, Woller, M. J., Muir, D. C. G., \& O’Hara, T. M. (2008). Dietary biomagnification of organochlorine contaminants in Alaskan polar bears. Canadian Journal of Zoology. 86 (3), 177-191.

Caldas, E. D., Coelho, R. L. C., Souza, K. R., \& Siba, S. C. (1999). Organochlorine pesticides in water, sediment and fish of Paranoia Lake of Brasilia, Brazil. Bulletin of Environmental Contamination and Toxicology, 62, 199-206. http://dx.doi.org/10.1007/s001289900860

Castilho, J. A. A., Fenzl, N., Guillen, S. M., \& Nascimento, F. S. (2000). Organochlorine and organophosphorus pesticide residues in the Atoya river basin, Chinandega, Nicaragua. Environmental Pollution, 110, 523-533. http://dx.doi.org/10.1016/S0269-7491(99)00277-8

Cremlyn, R. J. (1991). Agrochemicals Preparation and Mode of Action, New York, NY: John Wiley \& Sons.

Darko, G., \& Acquaah, S. O. (2007). Levels of organochlorine pesticide residues in meat. International Journal of Environmental Science and Technology, 4(4), 521-524.

DEH. (1997). Scheduled Waste Fact Sheet on Organochlorine Pesticides.

DPR. (2002). Environmental Guidelines and Standards for the Petroleum Industry in Nigeria (Revised edition), Department of Petroleum Resources, Ministry of Petroleum and Mineral Resources.

FAO (1990). Guideline for Soil Description. 3rd ed. (Review). Soil Resources Management and Conservation Services. Land and Water Development Division FAO Rome.

Gale, N. L., Adams, C. D., Wixson, B. G., Loftin, K. A., \& Huang, Y. (2004). Lead, zinc, copper and cadmium in fish and sediments from the Rig River and Flat River Creek of Missouri's Old Lead Belt. Environmental Geochemistry and Health, 26, 37-49. http://dx.doi.org/10.1023/B:EGAH.0000020935.89794.57

Hall, R. C. W. (1999). Long term psychological and neurological complications of lindane poisoning. Psychosomatics, 40(6), 513-517. http://dx.doi.org/10.1016/S0033-3182(99)71191-6

Hapeman, C. J., Schmidt, W. F., \& Rice, C. P. (1997). Structural and thermodynamic considerations in the isomeric conversion of endosulfan. 213th National Meeting of the American Chemical Society, San Francisco, California, USA, April 13-17, 1997. Abstracts of Papers: American Chemical Society 213 (1-3).

Hendershot, W. H., Lalande, H., \& Duquette, M. (1993). Soil reaction and exchangeable acidity. In (M. R. Carter Ed.) Soil Sampling and Methods of Analysis for Canadian Society of Soil Science, London: Lewis, pp. 141-145.

Ize-Iyamu, O. K., Abia, I. O., \& Egwakhide, P. A. (2007). Concentrations of residues from organochlorine pesticides in water and fish from some rivers in Edo State, Nigeria. Internationa. Journal of Physical Sciences, 2, 237-241.

Konstantinou, I. K., Hela, D. G., \& Albanis, T. A. (2006). The status of pesticide pollution in surface waters (rivers and lakes) of Greece. Part I. Review on occurrence and levels. Environmental Pollution, 141(3), 555-570.

Lemaire, G., Terouanne, B., Mauvais, P., Michel, S., Rahmania, R. (2004). Effect of organochlorine pesticides on human androgen receptor activation in-vitro. Toxicology and Applied Pharmarcology, 196, 235-246. http://dx.doi.org/10.1016/j.taap.2003.12.011 
NCEH. (2005). Centers for Disease Control and Prevention. Third National Report on Human Exposure to Environmental Chemicals. NCEH Pub. No. 05-0570.

Osibanjo, O. (1994). Review of Chlorinated Hydrocarbon Substances in African Aquatic Environment. F.A.O. Fish Report, 502, 37-45.

Osibanjo, O., \& Adeyeye, A. (1995). Organochlorine residues increase. Toxicology, 54, 460-465.

Osibanjo, O., \& Bamgbose, E. (1990). Review of chlorinated substances in marine fish and shellfish of Nigeria. Marine Polluition Bulletin, 21, 581-586. http://dx.doi.org/10.1016/0025-326X(90)90607-A

Pazou, E. Y. A., Lalèyè, P., Boko, M., van Gestel, C. A. M., Ahissou, H., Akpona, S., van Hattum, B., Swart, K., van Straalen, N. M. (2006). Contamination of fish by organochlorine pesticide residues in the Ouémé River catchment in the Republic of Bénin. Environment International, 32, 594-599. http://dx.doi.org/10.1016/j.envint.2006.01.003

Pope, J. V., Skurky-Thomas, M., \& Rosen, C. L. (1994). Toxicity: Organochlorine Pesticides, Medscape.

Quintero, A., Caselles, M. J., Ettiene, G., de Colmenares, N. G., Ramı'rez, T., \& Medina, D. (2008). Monitoring of organophosphorus pesticide residues in vegetables of agricultural area in Venezuela. Bulletin of Environmental Contamination and Toxicology, 81, 393-396. http://dx.doi.org/10.1007/s00128-008-9511-9

Rice, C. P., Hapeman, C. J., \& Chernyak, S. M. (1997). Experimental evidence for the interconversion of Endosulfan isomers. 213th National Meeting of the American Chemical Society, San Francisco, California, USA, April 13-17, 1997. Abstracts of Papers: American Chemical Society, 213, 1-3.

Sarkar, S. K., Bhattacharya, B. D., Bhattacharya, A., Chatterjee, M., Alam, A., Satpathy, K. K., Jonathan, M. P. (2008). Occurrence, distribution and possible sources of organochlorine pesticide residues in tropical coastal environment of India: an overview. Environment International, 34(7), 1062-1071. http://dx.doi.org/10.1016/j.envint.2008.02.010

Schulte, E. E. (Ed.). (1995). Recommended soil organic matter test. In Recommended Soil Testing Procedures for the North-eastern United State 2nd ed.

Shedrick, B. H. \& Wang, C. (1993). Particle size distribution. In (M. R.Carter, Ed.) Soil Sampling and Methods of Analysis for Canadian Society of Soil Science, London: Lewis. pp. 449-511.

Sparks, D. L. (2003). Environmental Soil Chemistry. 2nd Edition. San Diego: Academic Press.

Swackhamer, D., \& Hites, R. A. (1988). Occurrence and bioaccumulation of organochlorine compounds in fish from Siskiwit Lake, Isle Royale, Lake Superior. Environmental Science and Technology, 22, 543-548. http://dx.doi.org/10.1021/es00170a010

Townsend, L. R., \& Specht, H. B. (1975). Organophosphorus and organochlorine pesticide residues in soils and uptake by tobacco plants. Canadian Journal of Plant Science. 55, 835-842. http://dx.doi.org/10.4141/cjps75-129

USEPA Method 1699 (2007). Pesticides in Water, Soil, Sediment, Biosolids, and Tissue by High Resolution Gas Chromatography with High Resolution Mass Spectrometry.821-R-08-001.

Uyimandu, J. P. (2002). Comparative studies of organochlorine and PCBs in fish from the Lagos Lagoon and River Elber Saar. Journal of Agriculture Biotechnology and Environment, 4, 14-17.

Vitosh, M. L., John, J. W., \& Mengel, B. (1995). Tri-state recommendation for corn, soyabean and wheat. Extension Bulletin E. p. 252, New York.

WHO, Geneva (1990). Chemistry and Spefications of Pesticides. Thirteenth Report of the WHO Expert Committee on Vector Biology and Control, WHO, Geneva. 